\title{
Technology and Leapfrogging in high-tech industries: Evidence from the Disc Drive Industry
}

\author{
Hyung Rok Yim ${ }^{1}$ and Wonjin Jung ${ }^{2 *}$ \\ ${ }^{1}$ Associate Professor, School of Business, Hanyang University, South Korea \\ ${ }^{2}$ Professor, School of Business Administration, Dankook University, \\ South Korea \\ ${ }^{1}$ hryim@hanyang.ac.kr, ${ }^{2 *}$ jungw@dankook.ac.kr
}

\begin{abstract}
A generic curiosity prevailing in high-tech industries is that those firms owning topedge technologies frequently fail to lead market leadership. For tackling the issue, this paper attempts to explore a fundamental mechanism of why technological leapfrogging can occur. By this sense, a technology leader is considered to be owning a currently available best technology, which is denoted as BTS (best technology superiority). Firm specific technological potentiality, in a relative sense amongst incumbents, is denoted as PTS (potential technology superiority). According to our results, leapfrogging can occur in a longer-time span, which suggests that BTS can fail to lead market leadership; PTS rather than BTS can play a more important role in technology racing game ultimately. The most salient contribution of the paper is to directly scrutinize why owing technological potentiality needs to be treated differently from owning the best technology and, accordingly, why PTS plays a more important role in technology competition in the longrun. The empirical results exactly support those theoretic predictions.
\end{abstract}

Keywords: Technology, racing, leapfrogging, gap, and competition

\section{Introduction}

In high-tech industries, technological superiority has been considered as a key success factor [1] \& [2] and licensing is preferred as a strategic pathway to expand the product life cycle of new technologies [3]. Ironically, it is a common event that a market leader fails to maintain market leadership in high-tech industries. A fundamental curiosity accruing to this phenomenon is why leapfrogging by technologically inferior followers occurs very frequently in high-tech industries.

Surely, a key success factor in high-tech industries is technological superiority, which leads creative destruction that induces overlapping product life cycles [4]. The leapfrogging event reveals that current technological superiority might not be able to secure sustainable growth. Thus, technological superiority may fail to guarantee long-term market leadership. In fact, it is casually observed that technology leaders in high-tech industries experience frequent market exits.

The discrete-choice racing model by [5] provides a clue as to how leapfrogging can occur in high-tech industries and [6] simulates how technology shocks play a more important role in firm performance than market shocks do. From the perspective of technological superiority, the rigid disc drive industry is a unique industry with an emphasis on a rapidly evolving product life cycle, which results in frequent market exit. [7] is a pioneering work scrutinizing firm sustainability in the rigid disc industry. [8] introduces a scenario analysis under which scenario, through the mixtures of technology, product portfolio capability, or

Received (October 18, 2017), Review Result (January 10, 2018), Accepted (January 17, 2018)

* Corresponding Author 
marketing capability, incumbents can stay longer in the disc drive industry. In particular, [8] provides a useful dichotomy in terms of technological superiority. For instance, those incumbents owning the smallest disc drive in each product life cycle are considered to have an absolute technology advantage. On the other hand, all incumbents' storage capacities are normalized; the normalized storage capacity can gauge the degree of individual incumbent's relative technological superiority in the rigid disc industry. In this paper, absolute technology advantage is denoted as BTS (best technology superiority) and firm specific relative technology capacity is denoted as PTS (potential technology superiority)

Unfortunately, [8] does not provide any theoretic foundation as why PTS needs to be treated more importantly when leapfrogging is concerned. Thus, this paper aims at scrutinizing the impact of PTS on leapfrogging while contrasting with BTS. For this purpose, first, a two-stage Cournot type quantity competition model is established. In the first stage, a market leader owns a currently available best technology and, in the second stage, the chance for the market leader to obtain another best technology during the second stage is assumed to be depending on a stochastic process. Second, in each stage, equilibrium production quantities of both the market leader and a market follower are derived. Third, under which condition the market leader becomes to be able to maintain its market leadership is scrutinized. The theoretic predictions of the paper are tested by an empirical framework. Regression analyses are designed to test how market competition affects market exits. Probit analyses directly tackle how leapfrogging can occur in real competition.

This paper is organized as the follows. Section 2 explains competition structure and a generic risk, from the perspective of a technology leader, in maintaining market leadership is demonstrated. Section 3 derives the necessary and sufficient condition for leapfrogging and those theoretic predictions are empirically examined in Section 4. Section 5 summarizes.

\section{The Game Model}

\subsection{Competition Structure}

In the rigid disc industry, there are two firms $i$ and $j$. In the model, a two-stage product life cycle is constructed. $i$ is a market leader that has BTS at $t=1$ and $j$ is a follower that is assumed to have PTS. The inverse demand curve is given to $p_{t}=1-q_{t}^{i}-q_{t}^{j}$ where $t=1,2$; the market price is expected to decrease if either $q_{t}^{i}$ or $q_{t}^{j}$ increases.

The level of technology is measured by marginal cost; the lower the marginal cost is, the superior a firm's technology is. At $t=1, i$ owns the best technology defined as $c_{b, 1}^{i} \cdot j$ 's technology is given to $c_{m, 1}^{j}$ where $c_{b, 1}^{i}<c_{m, 1}^{j}$. At $t=1, i$ and $j$ solve (1) and (2), respectively.

$$
\begin{aligned}
& \max _{q_{1}^{i}}\left(p_{t}-c_{b, 1}^{i}\right) q_{1}^{i} \\
& \max _{q_{1}^{j}}\left(p_{t}-c_{m, 1}^{j}\right) q_{1}^{j}
\end{aligned}
$$

The equilibrium productions are derived as $q_{1}^{i *}=\frac{\left(1-c_{b, 1}^{i}\right)}{3}$ and $q_{1}^{j *}=\frac{\left(1-c_{m, 1}^{j}\right)}{3}$. As $i$ owns $c_{b, 1}^{i}$, it is $q_{1}^{i *}>q_{1}^{j *} ; i$ enjoys market leadership at $t=1$. At $t=2, i$ has two strategic pathways. It can either maintain market leadership by developing $c_{b, 2}^{i}$, i.e., the best technology at $t=2$, or just stay at $c_{b, 1}^{i}$ where $c_{b, 2}^{i}<c_{b, 1}^{i}$. One can interpret $c_{b, 1}^{i}$ as the old technology. In contrast, $j$ develops $c_{m, 2}^{j}$ where $c_{m, 2}^{j}<c_{m, 1}^{j}$. Unfortunately, $i$ becomes to lose it market leadership at $t=2$ if it fails to develop $c_{b, 2}^{i}$ because $c_{b, 1}^{i}$ is inferior to $c_{m, 2}^{j}$. 
$\left(c_{m, 2}^{j}<c_{b, 1}^{i}\right)$. Summarizing, the order of technologies is arranged as $c_{m, 1}^{j}>c_{b, 1}^{i}>c_{m, 2}^{j}>$ $c_{b, 2}^{i}$. Thus, $c_{b, 2}^{i}$ is the most advanced technology in the model.

With a probability of $p, i$ can earn $c_{b, 2}^{i}$ whilst $i$ remains to be $c_{b, 1}^{i}$ with $1-p$ at $t=2$; hence, $i$ 's stochastic R\&D (research and development) process is given to $p c_{b, 2}^{i}+(1-$ $p) c_{b, 1}^{i}$ at $t=2$. The equilibrium quantities of $i$ and $j$ are derived to be

$q_{2}^{i *}=\frac{\left\{1-p c_{b, 2}^{i}-(1-\mathrm{p}) c_{b, 1}^{i}\right\}}{3}$

$q_{2}^{j *}=\frac{\left(1-c_{m, 2}^{j}\right)}{3}$

Defining $Q^{i *}=q_{1}^{i *}+q_{2}^{i *}$ and $Q^{j *}=q_{1}^{j *}+q_{2}^{j *}$, then

$Q^{i *}=\frac{\left\{2-p\left(c_{b, 2}^{i}+c_{b, 1}^{i}\right)-2 c_{b, 1}^{i}\right\}}{3}$

$Q^{j *}=\frac{\left(2-c_{m, 1}^{j}-c_{m, 2}^{j}\right)}{3}$

In (5), the higher the $p$ is, the higher the $Q^{i *}$ is expected to increase while $Q^{j *}$ does not vary according to $p$. In other words, regardless of $j$ 's strategic investment, one can infer that the technology leader $i$ 's research and development capability can open a leapfrogging opportunity to $j$.

\subsection{The Risk Management of a Market Leader}

A hidden factor to affect $i$ 's strategic attitude is its propensity to risk management. A risk-taking market leader would adopt aggressive R\&D strategy in order to obtain $c_{b, 2}^{i}$ while affording a failure cost. In contrast, a risk-avoiding market leader would like to afford smaller failure risk for earning $c_{b, 2}^{i}$, which decreases the chance to earn $c_{b, 2}^{i}$ accordingly. For identifying $i$ 's propensity to risk, one needs to test production function. When $i$ 's production is exogenously determined by $p$ at $t=2$, its total production, i.e., $Q^{i-r^{*}}$ is defined as

$$
Q^{i-r^{*}}=q_{1}^{i *}+p \frac{\left(1-c_{b, 2}^{i}\right)}{3}+(1-p) \frac{\left(1-c_{b, 1}^{i}\right)}{3}
$$

Because of $\frac{\partial Q^{i}-r^{*}}{\partial p}=\frac{\left(c_{b, 1}^{i}-c_{b, 2}^{i}\right)}{3}>0$, the higher the $p$ is, the more quantity $i$ is able to produce, which can reinforce its market leadership. Proposition 1 implicitly reveals that $i$ becomes to be exposed to leapfrogging due to its risk management attitude; a risk averse $i$ is less inclined to invest for research and development in the next stage competition. Thus, it is generically exposed to the potential threat of $j$ 's leapfrogging.

Proposition 1. The market leader shows a risk averse attitude.

Proof. $Q^{i *}-Q^{i_{r}{ }^{*}}=\frac{(1-p) c_{b, 2}^{i}}{3}>0$ and thus $Q^{i}$ is a concave function. 


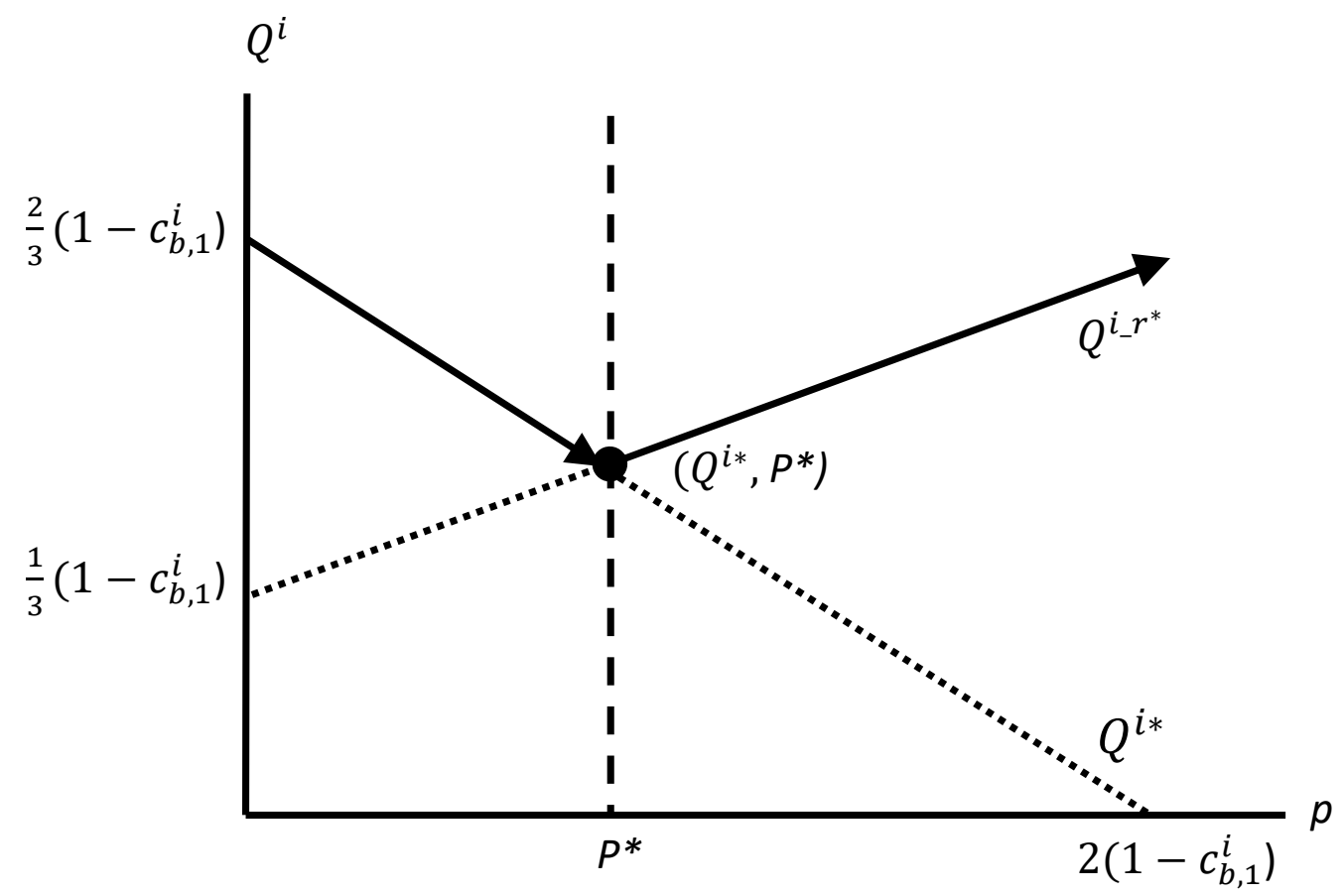

Figure 1. The Market Leader's Technological Superiority and Its Pathway

Figure 1 describes how $i$ 's risk averse attitude incurs a potential leapfrogging by $j$. If $p<p^{*}, i$ is less likely to produce at $c_{b, 2}^{i}$, which can allow $j$ 's leapfrogging. When $p \geq p^{*}$, its chance to maintain market leadership increases. However, by concavity, $i$ does not pursue aggressive R\&D strategy. Surely, $i$ 's chance to maintain market leadership shrinks endogenously unless it adopts an aggressive $\mathrm{R} \& \mathrm{D}$ strategy at $t=2$.

\section{Leapfrogging}

\subsection{The Necessary and Sufficient Condition}

Proposition 2 demonstrates that $i$ can lead market only when its chance to earn $c_{b, 2}^{i}$ at $t=2$ satisfies $p>\frac{c_{m, 2}^{j}-c_{b, 1}^{i}}{\left(c_{b, 2}^{i}-c_{b, 1}^{i}\right)}$. Alternatively stated, $i$ can lose its market leadership if it fails to secure the threshold. From the perspective of a longer-time span, this prediction is verified by Proposition $3 ; i$ might not be able to lead its technological advantage succinctly because the lower bound for $p$ needs to be.

Proposition 2. At $t=2$, $i$ can lead its technology superiority if $p>\frac{c_{b, 1}^{i}-c_{m, 2}^{j}}{\left(c_{b, 1}^{i}-c_{b, 2}^{i}\right)}$.

$$
\text { Proof. At } t=2, q_{2}^{i *}>q_{2}^{j *} \text { if } \frac{\left\{1-p c_{b, 2}^{i}-(1-\mathrm{p}) c_{b, 1}^{i}\right\}}{3}>\frac{\left(1-c_{m, 2}^{j}\right)}{3} \text {. }
$$

Proposition 3. The market leader's chance to earn the next best technology is generically bounded by the nature of technology race.

Proof. $i$ 's competitive strategy for securing $Q^{i *}>Q^{j *}$ at $t=2$ becomes feasible if $p \leq$ $\frac{c_{m, 1}^{j}+c_{m, 2}^{j}-2 c_{b, 1}^{i}}{\left(c_{b, 2}^{i}+c_{b, 1}^{i}\right)}$.

Q.E.D. 


\subsection{The Feasibility of Leapfrogging}

Proposition 4 suggests that $c_{b, 1}^{i}$ is a proxy for a potential leapfrogging. If $c_{b, 1}^{i}$ is superior to the average level of $j$ 's technology during $t=1 \& 2$, then $i$ is able to enjoy its market leadership. Thus, an original technology gap endowed at $t=1$ plays the most important role in $j$ 's potential leapfrogging at $t=2$. By Propositions 2 and 3, the necessary and sufficient condition for $i$ 's market leadership at $t=1 \& 2$ is given to Figure 2 . When the upper bound for $p$ is limited, $j$ can leapfrog $i$ if $p \leq \frac{c_{b, 1}^{i}-c_{m, 2}^{j}}{\left(c_{b, 1}^{i}-c_{b, 2}^{i}\right)}$.

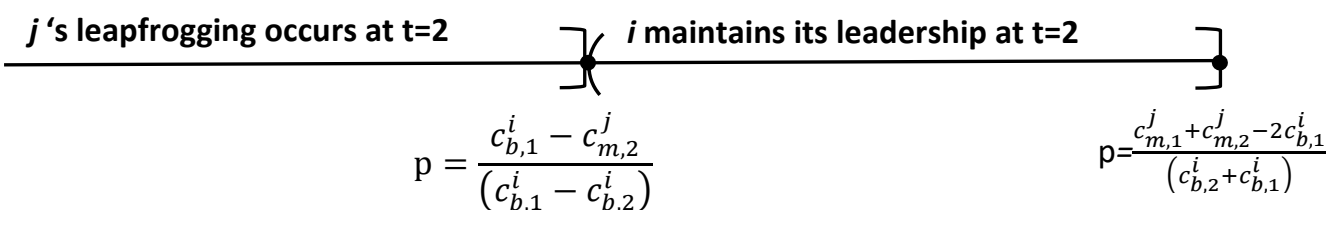

Figure 2. The Feasibility of $p$ and Leapfrogging Event

Proposition 4. The current level of $i$ 's technology is a fundamental competitive source for the technological gap against $j$ in the long-run technology racing game.

Proof. By Figure $1, Q^{i *}>Q^{j *}$ is satisfied only when $c_{b, 1}^{i}<\frac{c_{m, 1}^{j}+c_{m, 2}^{j}}{2}$.

The best technology does not guarantee $i$ 's long-term market dominance. Only when $c_{b, 1}^{i}<\frac{c_{m, 1}^{j}+c_{m, 2}^{j}}{2}, i$ 's $B T S$ can secure $i$ 's market leadership. Alternatively speaking, $j$ can leapfrog $i$ if $c_{b, 1}^{i} \geq \frac{c_{m, 1}^{j}+c_{m, 2}^{j}}{2}$. So, in the long-run, PTS enables $j$ to compete successfully against $i$. This suggests an important strategic implication; market followers become to have an opportunity to leapfrog if they have a capacity to trace the best technologies persistently through creative destruction process.

\section{Empirical Analysis}

\subsection{Empirical Framework}

Equations (8), (9), (10), and (11) are ordinary least square regressions for estimating the impacts of technological variables on firm survival. In (8)-(11), the dependent variable $\left(y_{i, t}\right)$ represents the total survival years of $i$ at $t$. $c$ is a constant and $t$ represents time dummies from 1982 to 1997.

$n f_{i, t}$ represents the total number of incumbents in the rigid disc drive at $t . d m_{i, t}$ is the number of diameters, which represents the product portfolios of $i$; the higher the $d m_{i, t}$ is, the more $i$ is able to diversify in each disc category. In fact, $d m_{i, t}$ is a proxy for product life cycle. $n m_{i, t}$ is the total number of $i$ 's current models at $t$ and so it is a proxy for $i$ 's sales capability. In (8), (9), and (10), the square terms of $d m_{i, t}$ and $n m_{i, t}$ are used as explanatory variables because the contributions of both variables are supposed to be marginally increasing with diminishing scales. $\bmod _{i, t}$ is the ratio of $n m_{i, t}$ over $d m_{i, t}$, which measures the actual degree of $i$ 's sales capability with respect to product category.

$$
\begin{aligned}
& y_{i, t}=c+t+n f_{i, t}+d m_{i, t}+d m_{i, t}^{2}+e_{i, t} \\
& y_{i, t}=c+t+n f_{i, t}+n m_{i, t}+n m_{i, t}^{2}+e_{i, t}
\end{aligned}
$$




$$
\begin{aligned}
& y_{i, t}=c+t+n f_{i, t}+d m_{i, t}+d m_{i, t}^{2}+n m_{i, t}+n m_{i, t}^{2}+e_{i, t} \\
& y_{i, t}=c+t+n f_{i, t}+\bmod _{i, t}+e_{i, t}
\end{aligned}
$$

Probit model uses the standard normal distribution on the density of standard normal which is given to (12).

$\phi(z)=\frac{1}{\sqrt{2 \pi}} e^{-z^{2} / 2}$

When $\Phi(z)$ is the CDF, the probability to observe the event of $y=1$ is given to (13).

$$
\operatorname{Prob}(y=1)=\int_{-\infty}^{\beta^{\prime} x} \phi(t) d t=\Phi\left(\beta^{\prime} x\right)
$$

The marginal effect which gauges the impact of explanatory variable $x$ to the probability of $y=1$ is calculated as (14).

$$
\frac{\partial \operatorname{Prob}(y=1)}{\partial x}=\frac{\partial F\left(\beta^{\prime} x\right)}{\partial x}=f\left(\beta^{\prime} x\right) \beta
$$

Equations (15)-(18) are probit estimations. $s_{i}$ is a dummy that gives the value of one to those survivors till $t . s m_{i}$ is a dummy that gives the value of one to those owning the smallest disc drive at $t . t c_{i}$ is the technology index used in [8], which locates the storage capability of each $i$ at $t$. In the paper, $s m_{i}$ is a proxy for $B T S$ and $t c_{i}$ is a proxy for $P B S$.

$$
\begin{aligned}
& s_{i}=c+t+d m_{i, t}+n m_{i, t}+e_{i, t} \\
& s_{i}=c+t+d m_{i, t}+d m_{i, t}^{2}+n m_{i, t}+n m_{i, t}^{2}+e_{i, t} \\
& s_{i}=c+t+s m_{i}++t c_{i}+d m_{i, t}+n m_{i, t}+e_{i, t} \\
& s_{i}=c+t+s m_{i}+t c_{i}+d m_{i, t}+d m_{i, t}^{2}+n m_{i, t}+n m_{i, t}^{2}+e_{i, t}
\end{aligned}
$$

\subsection{Empirical Results}

Table 1 summarizes the estimation results for equations (15)-(18). It is an eye-catching result that the number of firms has significant and negative coefficients, which suggests that the higher the competition is, the more likely firms are expected to exit from the disc market. The is consistent to [9]. The number of diameters has significant and positive effects but its contribution to the longevity of incumbents is marginally decreasing. The number of models show exactly same results with the number of diameters. Between them, the latter has a larger impact. The ratio of the number of models over the number of diameters shows a significant and positive coefficient. 
Table 1. Regression: The Impact of Technological Superiority on Firm Survival

\begin{tabular}{|c|c|c|c|c|}
\hline Variables & (14) & (15) & (16) & $(17)$ \\
\hline Constant & $\begin{array}{c}2.7363 \\
(0.4895)\end{array}$ & $\begin{array}{c}2.6284 \\
(0.5037)\end{array}$ & $\begin{array}{c}2.6302 \\
(0.4818)\end{array}$ & $\begin{array}{c}2.8255 \\
(0.5513)\end{array}$ \\
\hline$n f_{i, t}$ & $\begin{array}{c}-0.3459 * * * \\
(0.1238)\end{array}$ & $\begin{array}{c}-0.2607 * * \\
(0.1279)\end{array}$ & $\begin{array}{c}-0.3189 * * * \\
(0.1221)\end{array}$ & $\begin{array}{c}-0.2505 * * \\
(0.1396)\end{array}$ \\
\hline $\begin{array}{l}d m_{i, t} \\
d m_{i, t}^{2}\end{array}$ & $\begin{array}{c}0.4115 * * * \\
(0.0922) \\
-0.0240 * * \\
(0.0184)\end{array}$ & - & $\begin{array}{c}0.3366 * * * \\
(0.1011) \\
-0.0257 \\
(0.0186)\end{array}$ & - \\
\hline $\begin{array}{l}n m_{i, t} \\
n m_{i, t}^{2}\end{array}$ & - & $\begin{array}{c}0.1371 * * * \\
(0.0180) \\
-0.0039 * * * \\
(0.0012) \\
\end{array}$ & $\begin{array}{c}0.0439 * \\
(0.0231) \\
-0.0004 \\
(0.0013) \\
\end{array}$ & - \\
\hline $\bmod _{i, t}$ & - & - & - & $\begin{array}{c}0.0613 * * * \\
(0.0164)\end{array}$ \\
\hline Y82 & $\begin{array}{c}-0.3460 \\
(0.1284)\end{array}$ & $\begin{array}{c}-0.3759 \\
(0.1298)\end{array}$ & $\begin{array}{c}-0.3565 \\
(0.1280)\end{array}$ & $\begin{array}{c}-0.3601 \\
(0.1354)\end{array}$ \\
\hline Y83 & $\begin{array}{c}-0.1468 \\
(0.1091)\end{array}$ & $\begin{array}{c}-0.2044 \\
(0.1119)\end{array}$ & $\begin{array}{c}-0.1656 \\
(0.1090)\end{array}$ & $\begin{array}{c}-0.1932 \\
(0.1187)\end{array}$ \\
\hline Y84 & $\begin{array}{l}-0.0901 \\
(0.1049)\end{array}$ & $\begin{array}{l}-0.1499 \\
(0.1098)\end{array}$ & $\begin{array}{l}-0.1090 \\
(0.1054)\end{array}$ & $\begin{array}{l}-0.1428 \\
(0.1166)\end{array}$ \\
\hline Y85 & - & - & - & - \\
\hline Y86 & $\begin{array}{l}0.0799 * \\
(0.0979)\end{array}$ & $\begin{array}{c}0.0506 \\
(0.1008)\end{array}$ & $\begin{array}{l}0.0715^{*} \\
(0.0972)\end{array}$ & $\begin{array}{c}0.0528 \\
(0.1082)\end{array}$ \\
\hline Y87 & $\begin{array}{l}0.0885^{*} \\
(0.0993)\end{array}$ & $\begin{array}{l}0.0818 * \\
(0.0984)\end{array}$ & $\begin{array}{l}0.0856 * \\
(0.0982)\end{array}$ & $\begin{array}{c}0.0996 \\
(0.1058)\end{array}$ \\
\hline Y88 & $\begin{array}{c}0.0723 \\
(0.1032)\end{array}$ & $\begin{array}{c}0.0355 \\
(0.1025)\end{array}$ & $\begin{array}{c}0.0506 \\
(0.1023)\end{array}$ & $\begin{array}{c}0.0699 \\
(0.1076)\end{array}$ \\
\hline Y89 & $\begin{array}{l}0.0824 * \\
(0.0972)\end{array}$ & $\begin{array}{l}0.0739 * \\
(0.0985)\end{array}$ & $\begin{array}{l}0.0744 * \\
(0.0966)\end{array}$ & $\begin{array}{c}0.0932 \\
(0.1038)\end{array}$ \\
\hline Y90 & $\begin{array}{l}0.0575 * \\
(0.0990)\end{array}$ & $\begin{array}{c}0.0019 \\
(0.1006)\end{array}$ & $\begin{array}{l}0.0404 * \\
(0.0987)\end{array}$ & $\begin{array}{c}0.0122 \\
(0.1096)\end{array}$ \\
\hline Y91 & $\begin{array}{l}-0.0588 \\
(0.1093)\end{array}$ & $\begin{array}{l}-0.0700 \\
(0.1122)\end{array}$ & $\begin{array}{c}-0.0634 \\
(0.1089)\end{array}$ & $\begin{array}{l}-0.0758 \\
(0.1215)\end{array}$ \\
\hline Y92 & $\begin{array}{c}-0.0573 * \\
(0.0965)\end{array}$ & $\begin{array}{l}-0.0581^{*} \\
(0.0982)\end{array}$ & $\begin{array}{c}-0.0672 * \\
(0.0946)\end{array}$ & $\begin{array}{c}-0.0127 \\
(0.1109)\end{array}$ \\
\hline Y93 & $\begin{array}{l}-0.0626^{*} \\
(0.0979)\end{array}$ & $\begin{array}{l}-0.0449 \\
(0.1012)\end{array}$ & $\begin{array}{c}-0.0670 * \\
(0.0960)\end{array}$ & $\begin{array}{l}-0.0075 \\
(0.1157)\end{array}$ \\
\hline Y94 & $\begin{array}{c}0.0205 \\
(0.1114)\end{array}$ & $\begin{array}{c}0.0577 \\
(0.1183)\end{array}$ & $\begin{array}{c}0.0227 \\
(0.1119)\end{array}$ & $\begin{array}{c}0.1242 \\
(0.1264)\end{array}$ \\
\hline Y95 & $\begin{array}{c}-0.0323 \\
(0.1321)\end{array}$ & $\begin{array}{c}0.0096 \\
(0.1303)\end{array}$ & $\begin{array}{l}-0.0315 \\
(0.1280)\end{array}$ & $\begin{array}{c}0.0545 \\
(0.1489)\end{array}$ \\
\hline Y96 & $\begin{array}{c}-0.1872 \\
(0.1684)\end{array}$ & $\begin{array}{c}-0.1441 \\
(0.1744)\end{array}$ & $\begin{array}{c}-0.1688 \\
(0.1675)\end{array}$ & $\begin{array}{c}-0.1572 \\
(0.1903)\end{array}$ \\
\hline Y97 & - & - & - & - \\
\hline $\begin{array}{c}R^{2} \\
\text { Obs. }\end{array}$ & $\begin{array}{c}0.2096 \\
840\end{array}$ & $\begin{array}{c}0.1819 \\
840\end{array}$ & $\begin{array}{c}0.2211 \\
840\end{array}$ & $\begin{array}{c}0.0650 \\
840\end{array}$ \\
\hline
\end{tabular}

$1 . *, * *$, and $* * *$ are significant at $10 \%, 5 \%$, and $1 \%$ respectively.

2. The numbers in the parentheses are White standard errors.

Tables 2-1 and 2-2 summarize probit analysis results. The chance to survive throughout the entire period becomes higher as the more diameters and models incumbents own. Between the two factors, the number of models rather than the number of diameters has 
larger impacts. Therefore, one can say that marketability plays a very important role in a long-term survival. What is important is that owning the smallest disc drive can decrease the chance to survive longer, which means that technological superiority is nothing with longevity. This result strongly suggests that the theoretic prediction of the previous section, which stresses out that technological leapfrogging can occur at any time.

Table 2-1. Probit: The Impact of Technology on Firms Survival

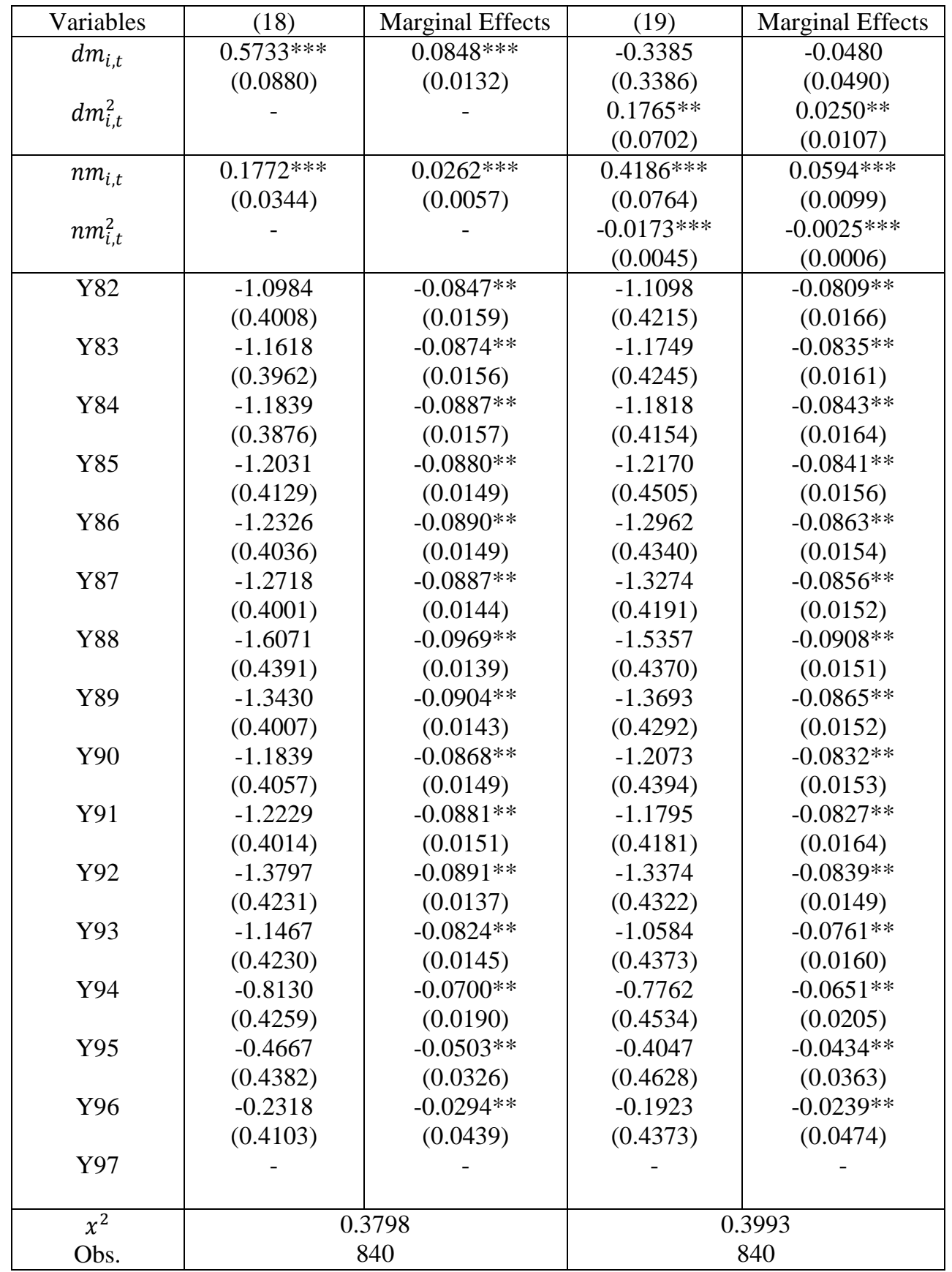

1. *, **,and $* * *$ are significant at $10 \%, 5 \%$, and $1 \%$ respectively. 
Table 2-2. Probit: The Impact of Technology on Firms Survival

\begin{tabular}{|c|c|c|c|c|}
\hline Variables & (7) & $\begin{array}{c}\text { Marginal } \\
\text { Effects }\end{array}$ & (8) & $\begin{array}{c}\text { Marginal } \\
\text { Effects }\end{array}$ \\
\hline$s m_{i}$ & $\begin{array}{c}-0.6190 * * * \\
(0.1808)\end{array}$ & $\begin{array}{c}-0.0641 * * * \\
(0.0156)\end{array}$ & $\begin{array}{c}-0.7103 * * * \\
(0.1912)\end{array}$ & $\begin{array}{c}-0.0658 * * * \\
(0.0155)\end{array}$ \\
\hline$t i_{i, t}$ & $\begin{array}{c}0.2624 * * * \\
(0.0581)\end{array}$ & $\begin{array}{c}0.0358 * * * \\
(0.0079)\end{array}$ & $\begin{array}{c}0.2744 * * * \\
(0.0608)\end{array}$ & $\begin{array}{c}0.0351 * * * \\
(0.0077)\end{array}$ \\
\hline $\begin{array}{l}d m_{i, t} \\
d m_{i, t}^{2}\end{array}$ & $\begin{array}{c}0.6486 * * * \\
(0.0945) \\
-\end{array}$ & $\begin{array}{c}0.0885 * * * \\
(0.0134) \\
-\end{array}$ & $\begin{array}{c}-0.2850 \\
(0.3417) \\
0.1806 * * \\
(0.0711)\end{array}$ & $\begin{array}{c}-0.0364 \\
(0.0447) \\
0.0231 * * \\
(0.0100) \\
\end{array}$ \\
\hline $\begin{array}{l}n m_{i, t} \\
n m_{i, t}^{2}\end{array}$ & $\begin{array}{c}0.1653 * * * \\
(0.0355) \\
-\end{array}$ & $\begin{array}{c}0.0226 * * * \\
(0.0054) \\
-\end{array}$ & $\begin{array}{c}0.4368 * * * \\
(0.0774) \\
-0.0196 * * * \\
(0.0045)\end{array}$ & $\begin{array}{c}0.0558 * * * \\
(0.0093) \\
-0.0025 * * * \\
(0.0005)\end{array}$ \\
\hline Y82 & $\begin{array}{l}-0.9539 \\
(0.4130)\end{array}$ & $\begin{array}{c}-0.0723 * * \\
(0.0165)\end{array}$ & $\begin{array}{c}-0.9316 \\
(0.4447)\end{array}$ & $\begin{array}{c}-0.0662 * * \\
(0.0174)\end{array}$ \\
\hline Y83 & $\begin{array}{l}-1.3937 \\
(0.4288)\end{array}$ & $\begin{array}{c}-0.0849 * * \\
(0.0137)\end{array}$ & $\begin{array}{l}-1.4250 \\
(0.4703)\end{array}$ & $\begin{array}{c}-0.0791 * * \\
(0.0144)\end{array}$ \\
\hline Y84 & $\begin{array}{l}-1.3858 \\
(0.4117)\end{array}$ & $\begin{array}{c}-0.0855^{* *} \\
(0.0142)\end{array}$ & $\begin{array}{l}-1.3954 \\
(0.4502)\end{array}$ & $\begin{array}{c}-0.0792 * * \\
(0.0150)\end{array}$ \\
\hline Y85 & $\begin{array}{l}-1.2379 \\
(0.4291)\end{array}$ & $\begin{array}{c}-0.0807 * * \\
(0.0142)\end{array}$ & $\begin{array}{l}-1.2527 \\
(0.4782)\end{array}$ & $\begin{array}{c}-0.0749 * * \\
(0.0148)\end{array}$ \\
\hline Y86 & $\begin{array}{l}-1.1913 \\
(0.4206)\end{array}$ & $\begin{array}{c}-0.0798 * * \\
(0.0147)\end{array}$ & $\begin{array}{l}-1.2423 \\
(0.4600)\end{array}$ & $\begin{array}{c}-0.0749 * * \\
(0.0153)\end{array}$ \\
\hline Y87 & $\begin{array}{l}-1.1470 \\
(0.4222)\end{array}$ & $\begin{array}{c}-0.0775 * * \\
(0.0147)\end{array}$ & $\begin{array}{l}-1.1678 \\
(0.4498)\end{array}$ & $\begin{array}{c}-0.0721 * * \\
(0.0154)\end{array}$ \\
\hline Y88 & $\begin{array}{l}-1.8329 \\
(0.4727)\end{array}$ & $\begin{array}{c}-0.0914 * * \\
(0.0134)\end{array}$ & $\begin{array}{l}-1.7635 \\
(0.4779)\end{array}$ & $\begin{array}{c}-0.0835 * * \\
(0.0147)\end{array}$ \\
\hline Y89 & $\begin{array}{l}-1.5508 \\
(0.4385)\end{array}$ & $\begin{array}{c}-0.0858 * * \\
(0.0134)\end{array}$ & $\begin{array}{l}-1.5936 \\
(0.4792)\end{array}$ & $\begin{array}{c}-0.0798 * * \\
(0.0144)\end{array}$ \\
\hline Y90 & $\begin{array}{l}-1.3580 \\
(0.4214)\end{array}$ & $\begin{array}{c}-0.0827 * * \\
(0.0136)\end{array}$ & $\begin{array}{l}-1.3989 \\
(0.4656)\end{array}$ & $\begin{array}{c}-0.0772 * * \\
(0.0144)\end{array}$ \\
\hline Y91 & $\begin{array}{l}-1.4551 \\
(0.4283)\end{array}$ & $\begin{array}{c}-0.0849 * * \\
(0.0137)\end{array}$ & $\begin{array}{l}-1.4012 \\
(0.4501)\end{array}$ & $\begin{array}{c}-0.0774 * * \\
(0.0151)\end{array}$ \\
\hline Y92 & $\begin{array}{l}-1.5436 \\
(0.4509)\end{array}$ & $\begin{array}{c}-0.0834 * * \\
(0.0129)\end{array}$ & $\begin{array}{l}-1.5112 \\
(0.4725)\end{array}$ & $\begin{array}{c}-0.0765 * * \\
(0.0141)\end{array}$ \\
\hline Y93 & $\begin{array}{l}-1.2010 \\
(0.4419)\end{array}$ & $\begin{array}{c}-0.0759 * * \\
(0.0135)\end{array}$ & $\begin{array}{l}-1.0943 \\
(0.4630)\end{array}$ & $\begin{array}{c}-0.0679 * * \\
(0.0149)\end{array}$ \\
\hline Y94 & $\begin{array}{l}-0.8048 \\
(0.4366)\end{array}$ & $\begin{array}{c}-0.0633 * * \\
(0.0179)\end{array}$ & $\begin{array}{l}-0.7443 \\
(0.4709)\end{array}$ & $\begin{array}{c}-0.0564 * * \\
(0.0196)\end{array}$ \\
\hline Y95 & $\begin{array}{l}-0.5703 \\
(0.4592)\end{array}$ & $\begin{array}{c}-0.0522 * * \\
(0.0259)\end{array}$ & $\begin{array}{l}-0.4917 \\
(0.4918)\end{array}$ & $\begin{array}{c}-0.0441 * * \\
(0.0293)\end{array}$ \\
\hline Y96 & $\begin{array}{l}-0.3367 \\
(0.4387)\end{array}$ & $\begin{array}{c}-0.0364 * * \\
(0.0364)\end{array}$ & $\begin{array}{l}-0.2921 \\
(0.4771)\end{array}$ & $\begin{array}{c}-0.0303 * * \\
(0.0394)\end{array}$ \\
\hline Y97 & - & - & - & - \\
\hline $\begin{array}{c}x^{2} \\
\text { Obs. }\end{array}$ & $\begin{array}{c}0.4088 \\
840\end{array}$ & & $\begin{array}{c}0.4317 \\
840\end{array}$ & \\
\hline
\end{tabular}

1. *, $* *$, and $* * *$ are significant at $10 \%, 5 \%$, and $1 \%$ respectively. 


\section{Conclusion}

In high-tech industries, technology leaders owning best technologies can secure their market leadership in the short-run. Nevertheless, market followers, even if they do not own best technologies, can leapfrog market leaders if the leaders fail to maintain technological gaps against followers. The game model in the paper analytically demonstrates why this phenomenon can occur.

Leapfrogging can occur if the market leader fails to lead technological gap against the follower. It is a surprising result that BTS can deteriorate incumbents' longevity while the stronger the PTS is, the longer the incumbents are expected to survive. This result suggests two important strategic implications. First, technology leaders can fail at any time in a longer time span. Second, technological potentiality is a fundamental competitive source for securing sustainable growth. Even if firms do not own best technologies in product life cycles, their technology capability that can keep track of technology race against market leaders enables them to leapfrog as smaller the technology gaps are. This is a fundamental reason why PTS is a key success factor in high-tech industries. Hence, it can be concluded that PTS is a leverage to outcompete in the long-run technology races

The empirical analyses were attempted in two ways. The regression estimation results clearly demonstrated that highly competitive environment can bring frequent market exits. Thus, it is a plausible causality that technological superiority cannot guarantee long-term survival. The probit estimation results reemphasized that those firms owning top-edged technologies in disc drive industry are less likely to survive longer. Rather, those firms that can keep track of technological evolution are more likely to survive longer.

\section{References}

[1] A. Glazer, "The Advantages of Being First", The American Economic Review, vol. 75, no. 3, (1985), pp. 473-480.

[2] J. M. Christopher, "Persistence of Technological Leadership: Emerging Technologies and Incremental Innovation", The Journal of Industrial Economics, vol. 59, no. 2, (2011), pp. 199-224.

[3] J. S. Gans and S. Stern, "Incumbency and R\&D Incentives: Licensing the Gale of Creative Destruction", Journal of Economics and Management Strategy, vol. 9, no. 4, (2000), pp. 485-511.

[4] B. Jovanovic and G. M. MacDonald, "The Life Cycle of a Competitive Industry", Journal of Political Economy, vol. 102, no. 2, (1994), pp. 322-47.

[5] J. F. Reinganum, "Practical Implications of Game Theoretic Models of R\&D", The American Economic Review, vol. 74, no. 2, (1984), pp. 61-66.

[6] H. R. Yim, "Quality Shock vs. Market Shock: Lessons from Recently Established Rapidly Growing U.S. Startups", Journal of Business Venturing, vol. 23, no. 2, (2008), pp. 141-164.

[7] J. Lerner, "Pricing and Financial Resources: An Analysis of the Disk Drive Industry", 1980-88, Review of Economics and Statistics, vol. 77, no. 4, pp. 585-98.

[8] H. R. Yim and J. W. Jung, "The Effects of Technological Advantages on Firm Survival in HDD Industry", Korean Corporation Management Review, vol. 12, no. 3, (2010), pp. 25-50.

[9] S. Klepper, "Entry, Exit, Growth, and Innovation over the Product Life Cycle", American Economic Review, vol. 86, no. 3, pp. 562-583. 